Al-Manhaj: Journal of Indonesian Islamic Family Law, 3 (2), 2021: 157-172

ISSN: 2715-003; E-ISSN 2714-5514

DOI: http://dx.doi.org/10.19105/al-manhaj.v3i2.5325

\title{
Childfree Pasca Pernikahan: Keadilan Hak-Hak Reproduksi Perempuan Perspektif Masdar Farid Mas'udi dan Al-Ghazali
}

\author{
Nano Romadlon Auliya Akbar \\ Muhammad Khatibul Umam \\ (Pascasarjana UIN Maulana Malik Ibrahim Malang, \\ nanoromadlon@gmail.com,umamkhotibul721@gmail.com)
}

\begin{abstract}
Abstrak:
Penelitian ini menyorot fenomena childfree yang mulai banyak terjadi dalam pernikahan Sebagai hal yang relatif baru di Indonesia, hak reproduksi seorang perempuan (istri) selama ini dipahami sebagai hak preogatif laki-laki (suami) sebagaimana juga fiqh klasik meyakininya. Kajian ini fokus pada 2 poin, salah satunya sudut pandang Masdar Farid Mas'udi mengenai fenomena childfree sebagai antitesa pemikiran ahli fiqh klasik khususnya Al-Ghazali. (This study highlights the phenomenon of childfree that is starting to happen a lot in marriage. As a relatively new thing in Indonesia, the reproductive rights of a woman (wife) have so far been understood as the prerogative of a man (husband) as classical fiqh also believes it. This study focuses on 2 points, one of which is Masdar Farid Mas'udi's point of view regarding the childfree phenomenon as the antithesis of classical fiqh experts, especially Al-Ghazali.)
\end{abstract}

\section{Kata Kunci:}

Childfree, hak reproduksi, keadilan, hukum Islam

\section{Pendahuluan}

Mengakarnya tradisi jahiliyah di kawasan Timur Tengah, seolah-olah menganggap reproduksi sebagai domain mutlak laki-laki. Masyarakat jahiliyah memandang perempuan sebagai konco wingking yang harus diperlakukan sebagai the second sex. Mitologi perempuan pra-Islam di kawasan ini mempersepsikan perempuan tidak layak 
mensejajarkan diri dengan laki-laki. Hak-hak reproduksi adalah hak preogatif laki-laki dan menjadi kewajiban suci perempuan melayani hak-hak laki-laki tersebut. Pandangan tersebut kemudian dibantah dengan kehadiran Islam yang memberikan hak-hak reproduksi yang seimbang antara laki-laki dan perempuan. ${ }^{1}$

Berbicara tentang hak-hak reproduksi perempuan dalam Islam, sudah pasti tidak lepas dari tinjauan fiqh, tepatnya figh al-nisa'. Yang dimaksud figh al-nisa' bukan hanya fiqh perempuan yang menyangkut persoalan perempuan dalam semua urusan, melainkan juga berbicara tentang reproduksi perempuan yang berkaitan dengan relasinya yaitu laki-laki. ${ }^{2}$

Hak yang terkait dengan reproduksi perempuan diantaranya: Pertama, hak untuk hidup, artinya adanya jaminan bagi perempuan untuk mendapatkan keselamatan dari resiko kematian karena kehamilan. Kedua, hak atas kebebasan dan keamanan. Artinya ada pengakuan terhadap keputusan setiap individu untuk menikmati dan mengatur kehidupan reproduksinya dan tidak seorangpun dapat dipaksa untuk hamil atau menjalani sterilisasi serta aborsi. Ketiga, hak atas kesetaraan dan bebas dari segala bentuk diskriminasi. Keempat, hak atas kerahasiaan pribadi yaitu adanya perlindungan terhadap hak pasien dalam mendapatkan informasi yang berhubungan dengan seksualitas dan kerahasiaan pribadi. Kelima,hak kebebasan berpikir yaitu berupa perlindungan kepada setiap orang untuk mengakses pendidikan dan informasi yang berkaitan dengan kesehatan reproduksi dan seksualitas mereka yang bebas dari pengaruh agama dan kepercayaan. ${ }^{3}$

Dalam kaitannya dengan hak reproduksi perempuan muncul fenomena childfree, sebuah isu yang belakangan ini rame diperbincangkan dalam media sosial yang mengatakan tidak ingin mempunyai anak setelah menikah. ${ }^{4}$ Childfree sendiri dimaknai sebagai keputusan keluarga (pasutri) untuk tidak mempunyai keturunan

\footnotetext{
${ }^{1}$ Nasruddin Umar, Teologi Reproduksi (Yogyakarta: Gama Media, 2002), 25.

2Mufidah. Ch. Psikologi Keluarga Islam Berwawasan Gender (Malang: UIN Maliki Press, 2013), 219

${ }^{3}$ Maria Ulfa Anshor, Fikih Aborsi Wacana Penguatan Hak Reproduksi Perempuan (Jakarta: Kompas, 2006), 4.

4https:// hot.liputan6.com/read/4646418/7-artis-ini-putuskan-tak-ingin-punya-anakpilih-adopsi-hingga-childfree, diakses Pada 16 Oktober 2021
} 
dengan berbagai macam alasan. Jika kita lihat lebih dalam lagi bahwa dalam tujuan berkeluarga salah satunya adalah mempunyai keturunan atau anak. Meski ketika nantinya akan mempunyai anak banyak sekali persiapan yang harus dilakukan oleh pasangan suami istri, seperti mengandungnya isteri dan persiapan melahirkan, serta masih banyak lagi persiapan yang harus dilakukan. Oleh karena wajar jika dewasa ini di saat wacana gender telah mencuat ke permukaan, keputusan untuk childfree mulai banyak diikuti. Meskipun seperti itu, fenomena ini menuai pro-kontra. Oleh sebab itu ada 2 pertanyaan penting yang dikemukakan dalam penelitian ini. Pertama, bagaimana hukum asal childfree. Kedua, bagaimana childfree dalam kacamata keadilan hak-hak reproduksi menurut Masdar Farid Mas'udi dan Al Ghazali.

\section{Metode Penelitian}

Jenis penelitian ini adalah studi pustaka (library reseach) dengan mengkaji beberapa sumber yang didapat dari literatur-literatur yang ada, serta pendapat para ahli yang sudah tertulis dan berkesinambungan dengan tema yang akan diteliti. Dengan itu, metode ini lebih mudah digunakan oleh penulis dalam mengkaji setiap hal yang berkaitan dengan topik kajian yang diteliti. Dalam penelitian ini literatur yang dipakai adalah kitab Ihya' Ulumiddin Al Ghazali sekaligus kitab syarahnya yakni Ithafus Sadaatil Muttaqin karya Al Zabiidi. Juga terdapat buku Masdar Farid Mas'udi yang berjudul Islam dan Hak Reproduksi sebagai pembanding literatur-literatur klasik tersebut serta beberapa literatur lain yang relevan.

\section{Hukum Asal Childfree}

Fiqh memotret fenomena childfree dengan mengilustrasikan kesepakatan suami-istri menolak mempunyai seorang anak. Oleh karenanya, pertanyaan hukum asal childfree dapat dijawab dengan melihat hukum childfree pada asalnya dalam fiqih, yakni sebelum sperma masuk pada rahim perempuan atau sebelum suami melakukan hubungan badan. Studi fiqih telah merekam beberapa padangan kasus yang hampir serupa sebelumnya, yaitu seperti: (1) sama sekali tidak menikah; (2) menahan diri untuk tidak bersetubuh pasca pernikahan; (3) 'Azl atau mengeluarkan sperma di luar vagina. Jika dicermati secara substansial semua kasus sama dengan pilihan childfree dengan sudut pandang menolak mempunyai anak sebelum berpotensi mempunyai 
(hamil). Imam al-Ghazali terkait hal ini menjelaskan hukum 'azl adalah boleh, tidak sampai makruh apalagi haram, sama dengan dua kasus pertama yang sama-sama sekadar meninggalkan keutamaan. Dalam syarh ihya'Imam Al-Ghazali menyebutkan:

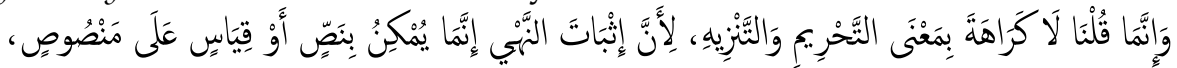

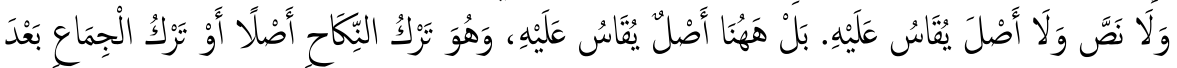

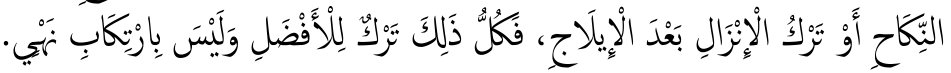

Kita mengatakan bahwa 'azl tidaklah makruh baik dengan Arti makruh tahrim dan makruh tanzih, lantaran buat memilih embargo terhadap suatu hal hanya bisa dipengaruhi menggunakan sumber dalam nash atau qiyâs dalam nash, meski tidak ditemukan nash atau qiyas yang dijadikan dalil embargo azl. Justru yang terdapat qiyâs yang melegalkannya, yaitu sama sekali tidak menikah, tidak berhubungan biologis pasca berkeluarga, atau mengeluarkan sperma sehabis memasukkan penis ke vagina. Sebab semuanya hanya adalah tindakan meninggalkan keutamaan, bukan pekerjaan yang bersifat larangan. 5

Oleh karena itu, apabila childfree adalah menolak mempunyainya anak sebelum sperma berada di rahim perempuan, maka hal tersebut masuk dalam kategori diperbolehkan. Kemudian bagaimana dengan hadis-hadis Nabi saw yang memerintakah menikah dan mempunyai keturunan? seperti dalam dua hadis berikut:

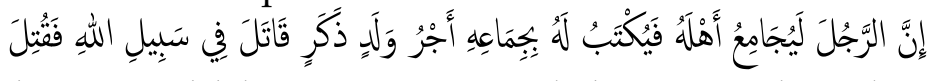

"Sungguh seorang lelaki niscaya menyetubuhi istrinya kemudian sebab persetubuhan itu pahala anak laki-laki yang berjihad fi sabilillah kemudian mati syahid". 6

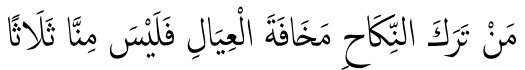

"Siapa saja yang meninggalkan nikah karena khawatir kesulitan mengurus anak istri maka tidak termasuk dariku. Nabi saw mengatakannya tiga kali."7

Hadis pertama di atas, dipandang oleh Imam Al-Ghazali sebagai jalan untuk memperoleh Musabbab mempunyai keturuan, yang

5Abu Hamid Al-Ghazali, Ihyâ' 'Ulûm al-dîn, (Beirut: Dâr al-Ma'rifah, 1997), 51

6Muhammad ibn Muhammad al-Husaini al-Zabidi, Ithâfu al-Sâdah al-Muttaqîn bi Syarh Ihyâa' '’ 'Ulûm al-Dîn, (Beirut: Muassasah al-Târîkh al-'Arabi, 1994 ), 379-380.

${ }^{7} \mathrm{Abu}$ al-Fadhl al-'Iraqi, al-Mughni 'an Haml al-Asfâr, (Riyadl: Maktabah Thabariyyah, 1995), 369. 
maka kita ketahui bahwa yang menjadikan anak dalam perempuan hanyalah Allah SWT. Dengan berhubungan suami istri dan mengeluarkan sperma di dalam rahim perempuan, suami sudah mendapatkan pahala sebab tadi.Karenanya al-Ghazali menilai hadis ini hanya bersifat anjuran dan boleh apabila ada orang memilih tidak melakukannya atau memilih tidak punya anak. ${ }^{8}$ Demikian juga hadis kedua di atas, Al-Ghazali melihat sabda Nabi: "Maka tidak termasuk dariku", maksudnya adalah tidak sesuai dengan yang diajarkan Nabi, yaitu perihal melakukan pilihan amal yang lebih utama. ${ }^{9}$

Konsistennya seorang Al-Ghazali dalam memegang pendapatnya, telah mendapat dukungan dari Al-Zabidi. Secara tegas Al-Zabidi menyatakan: "Karena sebenarnya seorang lelaki tidak diwajibkan menikah kecuali saat terpenuhi syarat-syaratnya. Sebab itu, bila menikah maka ia tidak wajib melakukan apapun kecuali menginap di suatu tempat bersama istri dan menafkahinya. Bila ia menyetubuhinya, maka tidak wajib baginya untuk inzâl atau memasukan sperma ke rahim istri. Karena itu, meninggalkan semua hal tersebut hanyalah meninggalkan keutamaan, tidak sampai makruh apalagi haram." 10 Dengan melihat pendapat Imam al-Ghazali dan juga Al-Zabidi yang membolehkan penolakan mempunyai anak sebelum potensial mempunyai, yaitu sebelum sperma berada di rahim perempuan, maka hemat penulis, hukum asal childfree adalah boleh. Meski hukum asalnya boleh, akan tetapi dapat berubah seiring dengan berbagai faktor yang mempengaruhinya.

\section{Motif-motif Childfree}

Setelah mengetahui bagaimana hukum asal praktek childfree, maka penelitian ini akan lebih ditekankan pada ranah kajian motif apa saja yang melatarbelakangi suami istri untuk mengikuti praktek childfree pada pernikahannya. Sangat banyak motif yang melatarbelakangi suami istri menentukan childfree. Adakalanya lantaran alasan ekonomi atau risi akan sebagai susah kehidupannya apabila punya anak, akan menciptakan sengsara anak pada masa

\footnotetext{
${ }^{8}$ Al-Ghazali, Ihyấ, 51.

${ }^{9} \mathrm{Al}-\mathrm{Ghazali}$, Ihyâa', 52.

10Teks Arab:

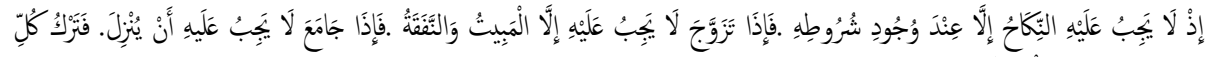

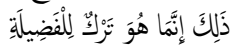

al-Zabidi, Ithâf..., 380.
} 
depannya, alasan kesehatan, alasan masih banyak anak-anak terlantar, semakin banyaknya populasi penduduk bumi, dan selainnya. Lalu bagaimana fiqh memandangnya? Masih dalam kerangka metode ijtihadnya Al-Ghazali yang mengatakan hukum asal childfree adalah diperbolehkan dan sekadar mengurangi keutamaan, apabila melihat beragam dari motifnya, maka dampak hukum childfree akan menyesuaikan motif yang melatarbelakanginya.

Apabila motif suami-istri dinilai ma'ruf, maka fiqh akan melegalkan. Apabila yang ada justru sebaliknya, maka ilegal menurut fiqh. Hal ini hampir mirip dengan penuturan Al-Ghazali yang menuai banyak kontra atas temuan hukumnya, dikatakan olehnya yang membolehkan tehadap kasus ini ialah sebelum adanya potensi, artinya sebelum sperma laki-laki masuk pada perempuan. Ghazali mengqiyaskan "Bila ada yang protes, Bila 'azl atau menumpahkan sperma di luar vagina istri saat bersetubuh hukumnya tidak makruh dari sisi menolak mempunyainya anak, maka bisa saja makruh karena niat atau motif buruk yang menyebabkan orang memilih menolak anak. Sebab penolakan terhadap mempunyainya anak tidak akan muncul kecuali dari niat yang rusak yang mengandung unsur-unsur syirik khafi (syirik yang samar)."

Al-Ghazali secara gamblang menjawabnya bahwa ketidakinginan seseorang mempunyai anak ada 5 motif, yang perlu digarisbawahi tidak semuanya motif tersebut dilarang oleh agama. Pada intinya Al-Ghazali menuturkan dalam tulisannya: Pertama, dalam tempo dahulu perbudakan manusia masih berlaku, sehingga tuannya yang notabene laki-laki hanya menjima' budak perempuannya dengan cara 'azl agar tidak punya anak, dengan kondisi seperti ini tuan tersebut tetap menjadikan budak perempuan itu sebagai hartanya, motif seperti itu legal dalam fiqh. Kedua, untuk tetap menjaga paras sang istri serta kualitas tubuhnya yang mana ketika sedang hamil atau setelah melahirkan bentuk dan wajah isteri berubah. Ketiga, sebab khawatir jika mempunyai keturunan, harus lebih giat lagi mencari nafkah dan pada akhirnya ditakutkan melakukan hal yang tidak haram. Maka motif seperti ini legal. Meski dengan motif atau bisa dibilang sebagai alasan, yang paling utama adalah tetap ikhtiyar dan bertakwa kepada Allah swt seiring firman-Nya: 


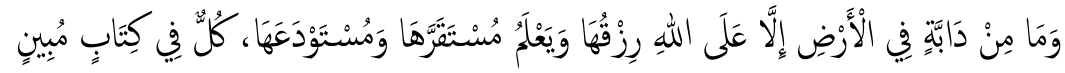

"Tidak satupun makhluk bergerak (bernyawa) di bumi melainkan semuanya dijamin oleh Allah rezekinya, Dia mengetahui tempat berdiam semua makhuk di dunia dan tempat menetapnya setelah kematian atau saat masih dalam rahim. Semua telah tertulis dalam kitab yang nyata (lauhul mahfûdh)." (Q.S. Hud: 6). ${ }^{11}$

Jika beranggapan repot karena memiliki anak tentu hal tesebut bertolak pada tawakkalnya, tetapi Al-Ghazali membantahnya bahwa motif itu tidak bisa serta merta dinilai sebagai pilihan salah. Keempat, memutuskan tanpa kehadiran anak sebab takut anak yang dilahirkan merupakan anak perempuan, sebagaimana keyakinan bangsa Arab jahiliyah tempo dulu. Inilah motif yang ilegal dalam Islam dan dia berdosa. Berdosa sebab timbul keyakinan yang keliru atas sunnah Nabi saw (memiliki anak). Kelima, tidak ingin mempunyai anak sebab terlalu menjaga kehigienisan diri, sangat ketat menjaga kebersihan diri, tidak mau melahirkan serta tidak mau nifas. Seperti ini juga termasuk motif yang rusak.12

Dari pemaparan Al-Ghazali di atas, motif childfree sangat menentukan halal-haramnya. Apabila childfree dipraktikan karena takut akan semakin repot hidupnya, menggangu karirnya, sangat takut menyusahkan anak di masa yang akan datang, sangat takut kelainan genetik menimpa anaknya, takut intensitas kegiatan seksualnya berkurang, melihat ribuan anak yang terlantar, over population, maka di sini hemat penulis relatif belum cukup dijadikan alasan untuk melarangnya. Berbeda ceritanya jika dilatarbelakangi keyakinankeyakinan keliru tentang memiliki buah hati (anak), contohnya adalah menilai jelek atau rendah pada setiap anak perempuan, juga adanya keyakinan sesat dengan melihat ainsan-insan baru yang terlahir ke dunia merupakan bagian dari sikap tercela turun temurun, itulah yang kemudian hemat penulis termasuk dari motif yang diharamkan.

\section{Childfree sebagai Prinsip Hidup}

Menarik sekali jika melihat pemikiran Sayyid Muhammad ibn Alawi al-Maliki untuk ditengok pada kasus ini, yaitu kasus

\footnotetext{
11Jalaluddin al-Mahalli dan Jalaluddin al-Suyuthi, Tafsîr al-Jalâlain, (Beirut: Darul Fikr, 2004), 259

12Al-Ghazali, Ihyâa', 52.
} 
pembatasan keturunan atau yang menurut penulis sangat nyentrik dengan fenomena childfree. Dalam kasus pengaturan lahirnya keturunan atau pembatasan anak, Sayyid Muahmmad membedakan antara membatasi mempunyai buah hati karena masalah ekonomi, atau membatasi keturuan karena keyakinan yang dianut. Pertama, tahdîdun nasl dalam lingkup personal pasangan suami istrikarena adanya beberapa alasan tertentu, maka menurutnya no problem, karena hal semacam itu adalah pilihan hidup dari masing-masing pasangan suami istri. Nabi Muhammad saw pun saat itu mengizinkan salah satu sahabatnya yang berkeinginan untuk tidak menginginkan kehadiran buah hati, sebagaimana disebutkan dalam riwayat hadis:

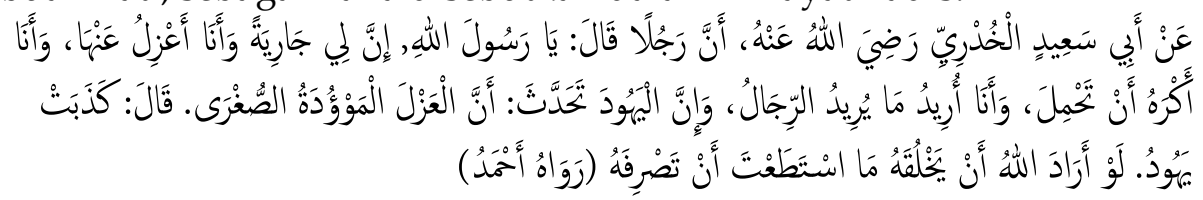

Artinya, "Diriwayatkan dari Abu Sa'id al-Khudri ra, sungguh seorang lelaki pernah berkata: 'Wahai Rasulullah, sungguh aku punya budak perempuan, dan aku 'azl atau menumpahkan sperma di luar vaginanya ketika bersetubuh. Aku tidak senang ia hamil dariku, aku punya kehendak sebagaimana kehendak para lelaki, sementara sungguh seorang Yahudi berkata: 'Sungguh 'azl merupakan pembunuhan bayi dalam skala kecil'.' Rasulullah saw lalu bersabda: 'Orang Yahudi itu bohong. Andaikan Allah menghendaki menciptakan anak, maka kamu tidak dapat menolaknya'.13

Kedua, tahdîdun nasl dalam konteks menjadikannya sebagai sebuahprinsip hidup semacam ideologi, dalam hal ini sikap kontra Sayyid Muhammad begitu terlihat. Beliau berkata:"Saya memiliki prnsip dan menggunakannya sebagai sikap beragama hanya dalam lingkup pemikiran pembatasan keturunan, sedangkan jika dijadikan sebagai pegangan hidup merupakan bagian dari pemikiran yang keji, termasuk tipu daya zionis yang sangat nyata. Pemikiran semacam itu merusak sebagian orang-orang dan menyebabkan fitnah dari kalangan elite agama. Kemudian mereka mempromosikan pemikiran tersebut dan bersemangat mengajak orang untuk mengikuti jalan hidupnya dengan alasan perihatin terhadap situasi ekonomi masayrakat Arab dan umat muslim, serta dengan alasan melindungi

13Ibn Hajar al-Asqalani, Bulûgh al-Marâm min Adillah al-Ahkâm, (Kediri, Dâr al-Ibâd, 2018), 205 
masyarakat dari kemiskinan, kebodohan, dan aneka ragam penyakit yang mulai muncul seiring dengan meningkatnya populasi manusia.". ${ }^{4}$

Larangan mempromosikan childfree sebagai ideologi menurut pemikiran Sayyid Muhammad tidak boleh; dan boleh bila dalam lingkup individu, hemat penulis antara childfree dengan membatasi keturunan sedikit berbeda, meskipun sama-sama menolak mempunyainya anak, namun motif childfree bisa beraneka ragam daripada tahdîdun nasl. Sebab tahdîdun nasl hanya membatasi keturunan, sedangkan childfree bisa saja dengan menolak mempunyainya anak dengan keyakinan yang salah. Sikap yang salah tersebut adalah mengharamkan dirinya untuk menikah, hal semacam ini termasuk yang dilarang dalam Islam, bahkan dinilai oleh Ibnu Hajar termasuk bagian dari macam kekufuran. Ibnu Hajar mengatakan:" Jika keengganan menikah seorang itu lantaran berpaling \& tetapkan diri berdasarkan nikah yang mengantarkan dalam keyakinan atas lebih unggulnya pilihan sikapnya daripada syariat nikah, maka maksud tidak termasuk golonganku pada sabda Nabi saw merupakan sesuatu yang tidak berada dalam agamaku. Sebab keyakinan misalnya itu adalah keliru satu macam berdasarkan kekufuran.".15

Jika studi fiqih ini mampu Diterima, maka mampu dirumuskan, sebagaimana restriksi keturunan dalam konteks menjadi prinsip biologi semacam ideologi dilarang, demikian pula mengkampanyekan childfree. Karenanya, tidak boleh berakibat childfree sebagai prinsip biologi atau ideologi, mengkampayekan dan mempromosikannya agar diikuti orang lain. Lain halnya childfree pada hal pertimbangan personal, semisal karena kekhawatiran beban ekonomi yang mampu menjerumuskan orang pada pekerjaanpekerjaan haram, alasan takut terjadi kesalahan genetik pada anaknya,

14Teks Arab:

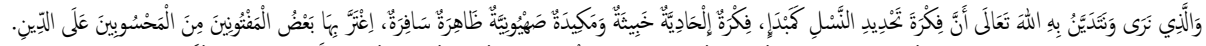

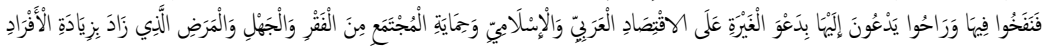

Muhammad ibn Alawi al-Maliki, Adab al-Islâm fî Nizhâm al-Usrah, (Surabaya: Haiah alShafwah al-Mâlikiyyah, 2001), 160.

15Teks Arab:

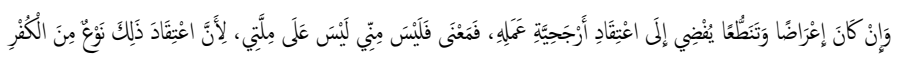
Abu al-Fadhl Ahmad ibn Ali ibn Hajar al-'Asqalani, Fath al-Bâri Syarh Shahîh al-Bukhâri, (Beirut: Dâr al-Ma'rifah, 1997), 106. 
maka seluruh itu tidak masalah, sebagaimana tahdîdun nasl pada konteks personal juga tidak masalah. Berkaitan hal ini Sayyid Muhammad mengatakan: "Perlu dicatat pembatasan keturunan itu harusnya tidak menjadi prinsip hidup, atau tidak menjadi pemikiran yang dikampanyekan untuk diikuti, atau dipromosikan kepada khalayak umum.".16

\section{Hak Reproduksi Perempuan dalam Pandangan Masdar Farid Mas'udi}

Menurut Masdar bahwa seorang perempuan dan laki-laki yang sudah menikah mempunyai hak dan kwajiban yang sama dalam hubungan seks. Oleh karena itu ada tiga ketagori hak kaum perempuan yang harus dipenuhi oleh suami kepada istri, diantaranya: hak jaminan kesehatan dan keselamatan, hak dan kewajiban kesejahteraan, serta hak dan kewajiban ikut bermusyawarah terkait hal yang menyangkut kepentingan perempuan. ${ }^{17}$ Dalam hal ini juga Masdar menegaskan bahwanya suami bukan hanya sebegai subjek dan istri sebagai objek, melainkan suami isteri berhak menjadi objek serta subjek dalam masalah reproduksi anak dan dalam berhubungan suami istri tidak ada yang mendominasi satu sama lain karena jika ada dominasi maka yang terjadi akan ada pengekangan hak dan eksistensi.

Masdar menekankan bahwa seorang isteri berhak menghendaki hamil dan menentukan jumlah anak yang diinginkan, hal semacam itu biarlah menjadi pilihan bebas dari individu yang bersangkutan. Pihak manapun tidak berhak untuk mengintervensi bahkan memaksakan kehendaknya dengan cara dan alasan apa pun juga. Karena pada nantinya yang menangggung resiko tentunya kedua belah pihak, terutama seorang isteri. ${ }^{18}$

Hal tersebut sebagaimana telah disebutkan dalam QS. AlBaqarah: 228 yang berbunyi:

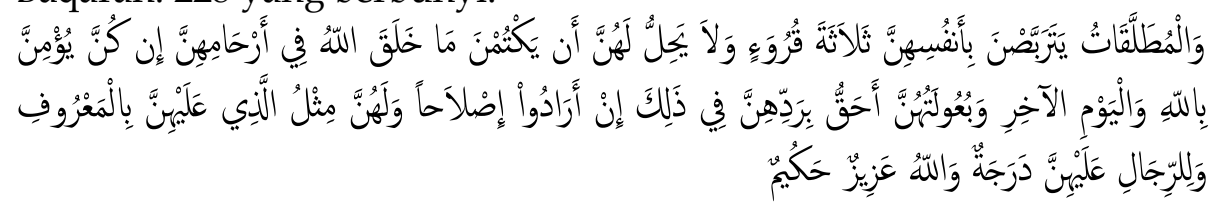

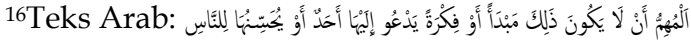

al-Hasani, Adabul..., 161.

17Mas'udi, Islam dan Hak Reproduksi..., 74.

${ }^{18} \mathrm{Mas}^{\prime} \mathrm{udi}$, Islam dan Hak Reproduksi..., 130.
} 
"Perempuan-perempuan yang ditalak hendaklah menahan diri (menunggu) tiga kali quru (suci). Tidak boleh mereka menyembunyikan apa yang diciptakan Allah dalam rahimnya, jika mereka beriman kepada Allah dan hari kiamat. Dan suami-suaminyua berhak merujukinya dalam masa menanti itu jika para suami menghendaki untuk islah. Dan para perempuan mempunyai hak yang seimbang dengan kewajibannya menurut cara yang ma'ruf. Akan tetapi para suami mempunyai satu tingkatan kelebihan daripada istrinya. Allah Maha Perkasa lagi Maha Bijaksana."

Menurut Masdar mengenai hak reproduksi, perempuan memiliki hak untuk memilih pasangan, menikmati hubungan badan, mempunyai keturunan, mengatur jarak kehamilan, cuti melahirkan dan menceraikan pasangannhya. Dari sini bisa dilihat bahwa kebutuhan perempuan untuk reproduksi sangatlah penting, dan apabila tidak digunakan sebagaimana mestinya tentunya keharmonisan dalam keluarga sulit tercapai, karna pada intinya dalam sebuah rumah tangga yang di nanti-nanti adalah buah hati atau keturunan. Hal itu bisa dicapai dengan mereproduksi. ${ }^{19}$

\section{Chlidfree dalam Tinjauan Hak Reproduksi Perempuan}

Umumnya para fuqaha' tidak menganggap hubungan seksual dan hak memiliki anak sebagai bagian dari hak-hak perempuan, namun justru ia dianggap sebagai bagian dari hak mutlak yang dimiliki oleh kaum Adam. Terlebih sebagian dari mereka ada yang berasumsi bahwa perempuan tidak memiliki hak talak karena telah ditinggal oleh suaminya dalam jangka waktu yang cukup lama. Nihilnya pengakuan tentang hak seksual bagi perempuan menjadikan pernikahan sebagai indikator penyimpangan dan kekerasan seksual, sebab perempuan juga mempunyai daya nafsu seksual yang sama dalam pernikahan, sebagaimana umumnya laki-laki. Seks adalah salah satu warna penting dalam pernikahan baik bagi laki-laki maupun perempuan. ${ }^{20}$

Hak yang mesti dijamin pemenuhannya di antaranya adalah hak reproduksi perempuan. Secara kualitatif mesti adil dengan hak-

\footnotetext{
19Seno Aris Sasmiti, Pemikiran Masdar Farid Mas'udi Tentang Hak Reproduksi Wanita, Buana Gender, Vol.5 Nomor 1, Januari-Juni 2020, 59

20 Muhammad Husein Fadhlullah, Dunia Perempuan dalam Islam (Jakarta: Lentera, 2000), 68-69.
} 
hak yang dimiliki oleh kaum Adam. ${ }^{21}$ Masdar memberikan sudut pandang kokoh yang menempatkan kaum Adam dan Hawa sebagai hamba Allah yang setara, di hadapan masyarakat dan di hadapan sesama. Perlu dipahami bersama bahwa masalah hak reproduksi perempuan merupakan suatu masalah yang kontroversial, meski adanya pembahasan di luar hukum Islam pastiny tetapa ada yang setuju dan tidak setuju. ${ }^{22}$

Hujjatal-Islam juga memaparkan bahwa melahirkan anak merupakan bagian dari ibadah kepada Allah dan tujuan dalam pernikahan. Karena ada empat alasan yang melatarbelakangi bahwa mempunyai seorang buah hati bagian dari ibadah: Pertama, sesuai dengan kecintaan Allah di dalam menghasilkan keturunan untuk berlangsungnya jenis manusia. Kedua, mencari kecintaan Nabi Muhammad dalam hal memperbayak ummat Nabi yang nantinya menjadi sebuah kebanggaan. Ketiga menuai kebaikan dari doa anak yang shalih. Keempat, mengharap syafaat dari kematian anak dalam usia masih kecil dan meninggal sebelum orang tuanya. ${ }^{23}$ Penuturan Imam al-Ghazali memahamkan kepada kita semua bahwa anak adalah tujuan pokok dari adanya bahtera pernikahan.

Kurang lebih ada empat fadhilah bagi orang tua yang berkenan melahirkan dan merawat seorang buah hati Tamtsil yang cukup indah dipaparkan al-Ghazali terkait pribadi yang memutuskan untuk tidak mempunyai buah hati: Sesungguhnya apabila seorang raja telah membawakan sebuah bibit tanaman kepada hambanya, disertai alat pertanian yang lengkap, kemudian disediakan juga bagi dia sebidang tanah untuk ditanam. Lalu ia sebenarnya mampu untuk menamam bibit tersebut. Namun jika ia bermalas-malasan, menyia-nyiakan alat pertanian yang lengkap, dan membuang bibit itu dengan sia-sia sehingga rusak, dan ia juga menolak untuk ada orang yang mewakilkan, maka sudah pasti membuat murka sang raja. ${ }^{24}$

${ }^{21}$ Masdar Farid Mas'udi, Islam dan Hak-Hak Reproduksi Perempuan (Bandung: Mizan, 1997), 75.

22Mas'udi, Islam..., 76.

23Teks Arab:

الأول موافقة حجة الله بالسعي في تصصيل الولد لإبقاء جنس الإنسان. والثاني طلب ححبة رسول الله صلى الله عليه وسلم في تكثير من مباهاته. والثالث طلب التبرك بدعاء الولد الصاح

Al-Ghazali, Ihyấ'..., 460. بعده. والرابع طلب الشغاعة بوت الولد الصغير إذا مات قبله الأله

24Teks Arab:

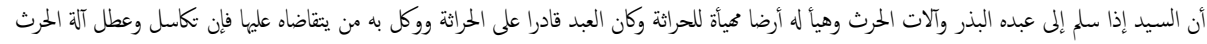

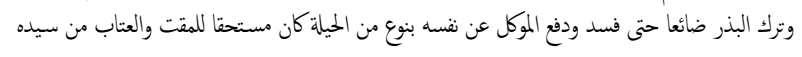


Pandangan al-Ghazali semacam itu memiliki konsekuensi bahwa apabila suami menghendaki memiliki seorang anak maka isteri tidak memiliki hak apapun untuk menolaknya selain menuruti kehendak suami, bahkan jika berusaha menolak akan diancam oleh murka Allah. Adalah konsep yang sudah tidak relevan lagi meskipun meletakkan posisi keturunan sebagai tujuan pokok dalam bahtera pernikahan. Terlebih bumi yang ditempati ini sudah kelebihan populasi manusia. Sebagai antitesa pandangan klasik tersebut, Masdar Farid Mas'udi mengatakan bahwa menetapkan keturunan sebagai tujuan pernikahan tidak realistis, karena beberapa alasan: Pertama, hadirnya buah hati adalah bukan bagian kuasa manusia. Karena buah hati adalah bagian amanah dari Allah yang wajib dijaga. Kedua, perlu direnungkan apabila tujuan pernikahan hanya untuk memperoleh anak saja, bagaimana jika ternyata tidak sesuai dengan ekspektasi memiliki anak, apakah nantinya dinyatakan tidak sah bahkan cacat hukum? Asumsi fiqh manapun tidak ada yang memandang bahwa kemandulan boleh menjadi alasan putusnya sebuah pernikahan. Betapa menderita hati seseorang jika karena faktor kodrati tidak memungkinkan memperoleh anak harus dianggap tidak berhak untuk menikah. Islampun demikian memandang tidak boleh seorang pun memikul beban yang diluar kuasanya. ${ }^{25}$

Terkait itu, pada zaman dahulu menentukan sebuah kehamilan masih belum terbayangkan apakah seorang isteri berhak memilih kehamilan atau menentukannya.Kehamilan pada saat itu lebih dipandang sebagai kehendak Tuhan yang tidak bisa diganggu gugat.Akan tetapi seiring perkembangan waktu, kehamilan dewasa ini dapat diatur jaraknya dengan menggunakan alat kehamilan. Sebagaimana dikenal di seantero dunia dengan sebutan Keluarga Berencana $(\mathrm{KB}) .{ }^{26}$

Mengenai relasi seksual-kehamilan tersebut, pandangan di atas mendapat dukungan dari kalangan pengikut mazhab Hanafi, mereka berasumsi bahwa yang berhak memutuskan mempunyai anak atau tidak adalah keduanya yaitu pasangan suami-istri. Secara logika

Al-Ghazali, Ihyâa'..., 460.

25Mas'udi, Islam..., 127.

${ }^{26}$ Maria Ulfa Anshor, Kesehatan Reproduksi Bagi Komunitas Islam (Jakarta: Pucuk Pimpinan Fatayat NU dan Yayasan Mitra Inti, 2005), 79. 
bahwa untuk memperoleh buah hati tentu tidak mungkin tanpa adanya partisipasi dari kedua belah pihak. Ini berarti relasi seksual kedua belah pihak menuntut untuk saling pengertian, bukan dengan paksaan terlebih kekerasan.

Akan tetapi fakta lapangan yang dijumpai saat ini sangatlah berbeda jauh dari tawaran konsep ideal relasi antara suami-istri. Pandangan keagamaan dewasa ini yang umum dijumpai dan dianut sangatlah bias nilai-nilai patriarkhi. Dalam arti hanya kaum Adam saja yang mempunyai hak monopoli seksual atas kaum Hawa, sehingga berbagai bentuk paksaan dan kekerasaan menjadi hal yang legal dan lumrah. Korbannya adalah istri sendiri, para istripun harus terpaksa menuruti nafsu biologis suami, Istri terbebani kewajiban memenuhi permintan seksual suami, tetapi tidak sebaliknya. ${ }^{27}$

Simpati atas fakta itu, ahli fiqh klasik yaitu Al-Syairazi berusaha mencari jalan tengah, ia berasumsi meski pada hukum awalnya isteri wajib melayani nafsu biologis suami, akan tetapi jika tidak ada keinginan dan kemampuan untuk melayaninya ia boleh menawarnya atau menangguhkannya sampai batas tiga hari. Juga bagi istri yang sedang tidak enak badan, maka tidak wajib baginya melayani nafsu biologis suaminya sampai sakitnya hilang. Jika suami tetap memaksa pada hakikatnya ia telah melanggar prinsip-prinsip mu'asyarah bil ma'rufdalam relasi suami-istri, dengan berperilaku kasar kepada pihak yang justru seharusnya dilindungi. Perlu diketahui dalam hubungan seks bersama istri, ia sama sekali bukanlah hanya sekedar objek, tetapi juga subjek. Maka karena sama-sama setara menjadi subjek tidaklah adil, jikalau hanya satu pihak saja yang merasakan kenikmatan dalam berhubungan biologis, sedangkan yang lainterkena getahnya dengan merasa tertekan dan terpaksa. ${ }^{28}$

Menyikapi aneka ragam macam pandangan tersebut, adalah dapat dinilai bijaksana hemat penulis dengan cara mempertanyakan kembali kepada pasangan suami-istri, apakah menghendaki mempunyai anak atau tidak, suami-istri boleh merencanakan mempunyai keturunan melalui hubungan badan yang sehat dan aman tanpa intervensi pihak manapun. Sehingga dapat memastikan dan muemutuskan dengan baikagar tidak rugi di kemudian hari. Karena

27Musdah Mulia, Muslimah Sejati (Bandung: Marja, 2011), 172.

${ }^{28} \mathrm{Mas}^{\prime}$ udi, Islam..., 120. 
kedudukan tertinggi dalam relasi suami-istri yaitu kedudukan relasi yang berkeadilan yang dilandasi dengan cinta dan kasih keduanya. Dalam pola relasi seperti ini, maka yang muncul tidak ada aku ataupun engkau, yang ada adalah kami/kita, sebagai fungsi dari yang kuat mengayomi dan melindungi pada kepentingan yang lemah.

\section{Penutup}

Berdasarkan pembahasan di atas maka dalam penelitian dapat disimpulkan setidaknya dua hal, yakni. Pertama hukum asalnya adalah boleh mesikpun nantinya hukum tersebut dapat berubah sesuai dengan motif yang melatar belakanginya. Termasuk di dalamnya adalah pandangan al-Ghazali dan Sayyid Muhammad yang mengatakan bahwa memutuskan tidak mempunyai anak atau menundanya perlu dilihat sebabnya. Kedua, dalam konteks keadilan hak hak reproduksi perempuan, Masdar Farid mengatakan bahwa perempuan mempunyai hak reproduksi yang harus terpenuhi. Artinya childfree ini bisa dilakukan jika suami istri menghendaki hal tersebut dan tidak ada yang merasa diberatkan satu sama lainnya.

Pemikiran Masdar Farid Mas'udi ini merupakan antitesa terhadap pemikiran fiqih klasik misalnya Imam al-Ghazali yang berpendapat bahwasanya hadirnya seorang buah hati adalah tujuan pokok dari adanya pernikahan. Dikatakan olehnya disyariatkan pernikahan itu sendiri adalah untuk tujuan memperoleh keturunan sebagai faktor keberlangsungan populasi manusia di dunia. Menyikapi aneka ragam macam pandangan tersebut, adalah dapat dinilai bijaksana dengan cara mendiskusikan kepada pasangan suami-istri masing-masing, menghendaki memiliki anak atau tidak nantinya suami-istri berhak merencanakan melalui hubungan seks yang ma'ruf tanpa intervensi pihak manapun. Sehingga dapat memastikan dan memutuskan dengan baik agar tidak rugi di kemudian hari.

\section{Daftar Pustaka}

Al-'Asqalani, Abu al-Fadhl Ahmad ibn Ali ibn Hajar, Fath al-Bâri Syarh Shahîh al-Bukhâri, (Beirut: Dâr al-Ma'rifah, 1997).

Al-'Iraqi, Abu al-Fadhl, al-Mughni 'an Haml al-Asfâr, (Riyadl: Maktabah Thabariyyah, 1995).

Al-Asqalani, Ibn Hajar, Bulûgh al-Marâm min Adillah al-Ahkâm, (Kediri, Dâr al-Ibâd, 2018). 
Al-Ghazali, Abu Hamid, Ihyâ' 'Ulûm al-Dîn, (Beirut: Dâr al-Ma'rifah, 1997).

Al-Hasani, Muhammad ibn Alawi al-Maliki, Adab al-Islâm fî Nizhâm alUsrah, (Surabaya: Haiah al-Shafwah al-Mâlikiyyah, 2001).

Al-Mahalli, Jalaluddin dan al-Suyuthi, Jalaluddin, Tafsîr al-Jalâlain, (Beirut: Darul Fikr, 2004).

Al-Zabidi, Muhammad ibn Muhammad al-Husaini, Ithâf al-Sâdah Muttaqîn bi Syarh Ihyâ' 'Ulûmiddîn, (Beirut: Muassasah Târîkh al'Arabi, 1994 ).

Anshor, Maria Ulfa, Kesehatan Reproduksi Bagi Komunitas Islam (Jakarta: Pucuk Pimpinan Fatayat NU dan Yayasan Mitra Inti, 2005).

Anshor, Maria Ulfa, Fikih Aborsi Wacana Penguatan Hak Reproduksi Perempuan (Jakarta: Kompas, 2006).

Fadhlullah, Muhammad Husein, Dunia Perempuan dalam Islam (Jakarta: Lentera, 2000).

https://hot.liputan6.com/read/4646418/7-artis-ini-putuskan-takingin-punya-anak-pilih-adopsi-hingga-childfree.(diakses pada 16 oktober 2021)

Mas'udi, Masdar Farid, Islam dan Hak-Hak Reproduksi Perempuan (Bandung: Mizan, 1997).

Mufidah. Ch. Psikologi Keluarga Islam Berwawasan Gender (Malang: UIN Maliki Press, 2013).

Mulia, Musdah, Muslimah Sejati (Bandung: Marja, 2011).

Sasmiti, Seno Aris, Pemikiran Masdar Farid Ma'udi Tentang Hak Reproduksi Wanita, Buana Gender, Vol.5 Nomor 1, Januari-Juni 2020, 59

Umar, Nasaruddin, Teologi Reproduksi (Yogyakarta: Gama Media, 2002). 